\title{
State of the Art
}

\section{Nuclear Factor $\kappa B$, Airway Epithelium, and Asthma Avenues for Redox Control}

\author{
Yvonne M. W. Janssen-Heininger ${ }^{1}$, Matthew E. Poynter ${ }^{2}$, Scott W. Aesif ${ }^{1}$, Cristen Pantano ${ }^{1}$, Jennifer L. Ather ${ }^{1}$, \\ Niki L. Reynaert ${ }^{3}$, Karina Ckless ${ }^{1}$, Vikas Anathy ${ }^{1}$, Jos van der Velden ${ }^{1}$, Charles G. Irvin ${ }^{2}$, and Albert van der Vliet ${ }^{1}$
}

Departments of ${ }^{1}$ Pathology and ${ }^{2}$ Medicine, University of Vermont College of Medicine, Burlington, Vermont; and the ${ }^{3}$ Department of Respiratory Medicine, Maastricht University Medical Center, Maastricht, The Netherlands

\begin{abstract}
A wealth of recent studies points to the importance of airway epithelial cells in the orchestration of inflammatory responses in the allergic inflamed lung. Studies also point to a role of oxidative stress in the pathophysiology of chronic inflammatory diseases. This article provides a perspective on the significance of airway epithelial cells in allergic inflammation, and reviews the relevance of the transcription factor, nuclear factor $\kappa \mathrm{B}$, herein. We also provide the reader with a perspective on the role that oxidants can play in lung homeostasis, and address the concept of "redox biology." In addition, we review recent evidence that highlights potential inhibitory roles of oxidants on nuclear factor $\kappa B$ activation and inflammation, and discuss recent assays that have become available to probe the functional roles of oxidants in lung biology.
\end{abstract}

Keywords: epithelium; nuclear factor $\kappa \mathrm{B}$; asthma; oxidants

\section{INFLAMMATION, ALLERGIC AIRWAYS DISEASE, AND THE IMPORTANCE OF AIRWAY EPITHELIUM}

Numerous cell types have been demonstrated to play a cardinal role in the pathophysiology of asthma (1). Bronchial epithelial cells represent an essential component of the innate immune system, and have emerged as a critical cell type that transduces proinflammatory signals in response to inhaled antigen or allergens. Bronchial epithelial cells are in direct contact with inhaled materials, including pollutants, allergens, proteases, microbes, and other factors that are relevant to the development of human asthma. Epithelial cells are capable of sensing and mounting a rapid response to these inhaled materials, and they express a variety of pattern recognition receptors (PRR) such as Toll-like receptors (TLR), and protease-activated receptors (PAR), which recognize microbial motifs and allergens (2) (Figure 1). Activation of Nod-like receptors (NLR) in response to microbial proteins or metabolic stress and subsequent inflammasome activation causes processing and release of the cytokine interleukin (IL)-1 $\beta$ (3). The activation of epithelial cells through these diverse pathways results in the production of chemokines and cytokines with the potential to attract inflammatory dendritic cells (DCs) to the lung and to induce the maturation of these and resident DCs so that they

(Received in original form June 24, 2008; accepted in final form January 22, 2009) Funded by the National Institutes of Health (NIH) grants R01HL60014 and R01HL079331 (Y.M.W.J.-H.).

Correspondence and requests for reprints should be addressed to Yvonne M. W. Janssen-Heininger, Ph.D., Department of Pathology, University of Vermont College of Medicine, 89 Beaumont Avenue, Burlington, VT 05405. E-mail: yvonne.janssen@uvm.edu

Proc Am Thorac Soc Vol 6. pp 249-255, 2009

DOI: $10.1513 /$ pats.200806-054rm

Internet address: www.atsjournals.org can activate $\mathrm{T}$ cells in the draining lymph nodes. Another important facet of the airway epithelium constitutes its barrier function, the first line of defense that prevents access of allergens to resident DCs. Loss of epithelial barrier function as a consequence of proteases associated with allergens, environmental pollutants, and so on results in the enhanced access of antigen to DCs. Uptake of antigens by DCs and their maturation through epithelial-derived factors promotes the interaction of DCs with T cells, and the differentiation of naïve $\mathrm{T}$ cells to Th2-polarized effectors. Th 2 cells produce a range of mediations that have the potential to cause airway remodeling and hyperresponsiveness (2) (Figure 1).

\section{NUCLEAR FACTOR $\kappa B$, ACTIVATION, AND REGULATION}

The transcription factor, nuclear factor $\kappa \mathrm{B}(\mathrm{NF}-\kappa \mathrm{B})$, has been considered the master regulator of both innate and adaptive immune responses and has been demonstrated to play a cardinal role in allergic airways disease. Therefore, understanding the various facets of regulation of $\mathrm{NF}-\kappa \mathrm{B}$ and its targets offers the potential to advance our understanding of immune processes in asthma. The family of $\mathrm{NF}-\kappa \mathrm{B}$ comprises five related proteins: p50, p52, RelA (also known as p65), c-Rel, and RelB. These factors can homo- and heterodimerize through the rel homology domain. Only RelA, c-Rel, and RelB contain a transcriptional activation domain, while p50 and p52 lack this, and can only activate transcription through heterodimerization with RelA, c-Rel, or RelB $(4,5)$. NF-кB is kept sequestered in the cytoplasm of unstimulated cells bound to IкB proteins. In response to a wide array of stimuli, IкB proteins are phosphorylated by the serine kinase; inhibitor of kappa B kinase (IKK). Phosphorylated IкBs are ubiquitinated and degraded by the $26 \mathrm{~S}$ proteosome, unmasking the NF-кB nuclear localization signal, allowing NF- $\mathrm{BB}$ to accumulate in the nucleus. IKK functions in a large molecular weight complex, the IKK signalsome (see below) that contains $\operatorname{IKK} \alpha$ and $\operatorname{IKK} \beta$, which contain kinase activity, and IKK $\gamma$, also known as NEMO, which acts as a regulatory protein (6). At least two parallel pathways of IKK-induced NF- $\mathrm{B}$ B have been described (Figure 2). In the canonical pathway, activation of IKK $\beta$ by many stimuli, including cytokine TNF- $\alpha$, TLR agonists, and IL- $\beta$ leads to the phosphorylation of $\mathrm{I} \kappa \mathrm{B} \alpha$ at Serines 32 and 36 (7). In the noncanonical pathway, NF-кB-inducing kinase (NIK) phosphorylates IKK $\alpha$. IKK $\alpha$ subsequently phosphorylates p100, which causes its proteolytic processing to p52 (8), allowing p52/RelB dimeric complexes to translocate to the nucleus (4). Activators of the noncanonical pathway include subsets of stimuli that include B cell-activating factor (BAFF), lymphotoxin $\beta$ (LT $\beta$ ), and CD40 ligand (CD40L), as well as lipopolysaccharide (LPS). It is generally held that the noncanonical pathway is necessary for the adaptive immune response, while 


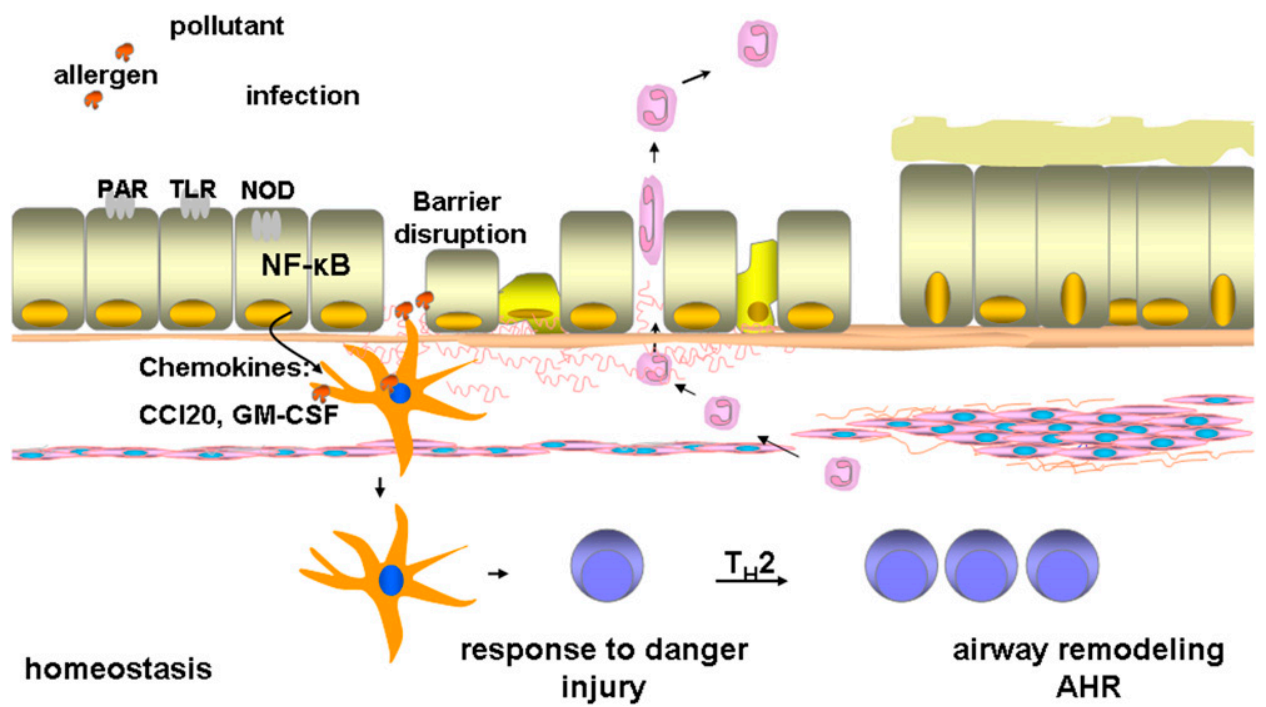

Figure 1. Schematic presentation of the functional role of airway epithelium in the pathogenesis of asthma. Epithelial cells, which are positioned at the interface with the environment, can sense and respond to inhaled antigens, allergens, pollutants, proteases, microbes, through the activation of Toll-like receptors (TLR), Nod-like receptors (NOD), and protease activated receptors (PAR), and others, leading to the activation of nuclear factor $\kappa \mathrm{B}(\mathrm{NF}-\mathrm{\kappa} B)$. Activation of $N F-\kappa B$ leads to the transcriptional activation of many proinflammatory genes that include cytokine and chemokines, granulocyte macrophage-colony-stimulating factor (GM-CSF), and CC chemokine ligand 20 (CCL20). Disruption of the epithelial barrier as a result of inhaled pollutants, or proteases present in allergens, results in enhanced access of antigens to dendritic cells (DCs). The increased recruitment and activation of DCs through the actions of CCL20 and GM-CSF, and enhanced accessibility of antigen result in maturation of DCs, and their polarization, leading to subsequent Th2 immune responses, critical to airway remodeling.

the canonical pathway is required for the onset of the innate immune response (9), although crosstalk between these pathways exists to control of the strength and duration of the transcriptional response (10). Noncanonical p52/RelB dimers use a unique consensus site. This site, PuGGAGAPyTTPu $(\mathrm{Pu}$; purine, Py; pyrimidine), contrasts the consensus NF-кB-binding sequence of the canonical pathway, GGGPuNNPyPyCC $(\mathrm{Pu}$; purine, Py; pyrimidine, N; any base) (Figure 2). The use of

\section{Canonical pathway}

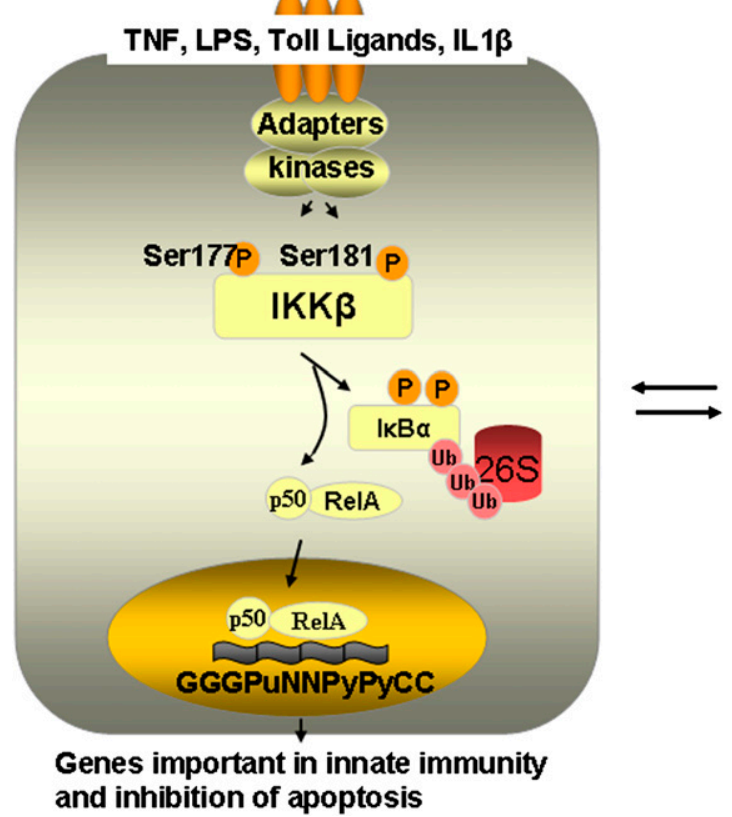

Non-canonical pathway

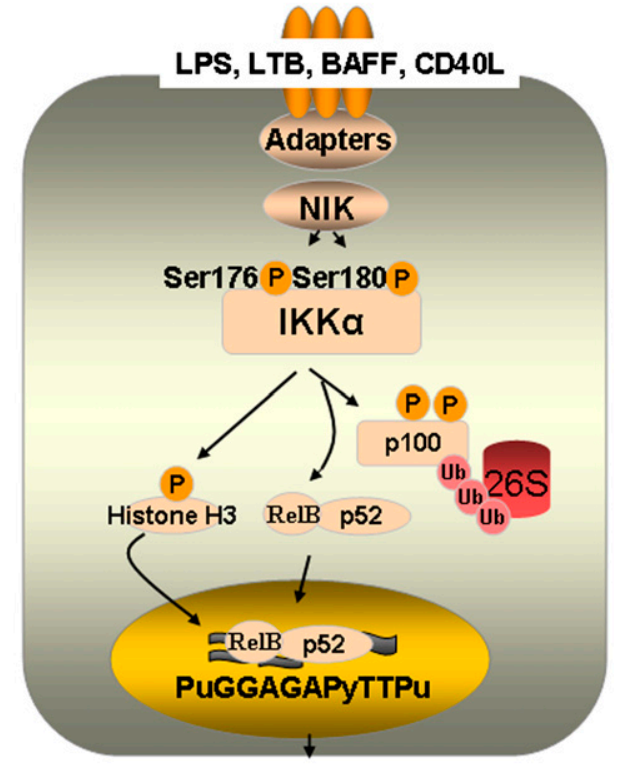

Genes important in adaptive immune responses
Figure 2. Overview of NF$\kappa \mathrm{B}$ activation pathways. In the canonical NF- $\mathrm{kB}$ activation pathway, which is stimulated by ligands such as tumor necrosis factor (TNF)- $\alpha$, lipopolysaccharide (LPS), and interleukin (IL) $-1 \beta$, IKK $\beta$ is responsible for the phosphorylation of $I_{\kappa} B \alpha$, leading to its subsequent ubiquitination and degradation through the proteasome pathway. This allows for translocation of RelA/p50 to the nucleus, and the subsequent activation of transcription of genes important in innate immunity and protection from apoptosis. In the noncanonical (alternative) NF$\kappa B$ activation pathway, which is activated through ligands such as lymphotoxin $\beta$ (LTB), B cell-activating factor (BAFF), and

CD40 ligand (CD40L), among others, NF-KB-inducing kinase (NIK)-dependent activation of IKK $\alpha$ leads to phoshorylation of p100, subsequent ubiquitination, and proteolytic processing to p52. This results in nuclear translocation of p52/RelB complexes, and activation of distinct transcriptional programs. For illustrative purposes, this is a simplified overview. Additional phosphorylation events are induced by IKK proteins, notably the phosphorylation of histone H3, CREB-binding protein, and silencing mediator of retinoic acid and thyroid hormone receptor by IKK $\alpha$. Additional post-translational modifications of NF- $\mathrm{B}$ members that include phosphorylation, ubiquitination and acetylation, function of transcriptional co-activators and repressors, and chromatin remodeling events are collectively important to shape the nature, strength, and duration of the NF-кB transcriptional response. While the canonical and noncanonical pathways are drawn separately for illustrative purposes, we point out that these pathways do not act independently. Both cooperative and inhibitory roles in reciprocal regulation have been reported, indicated by arrows (see References 10 and 47 for recent reviews). 
distinct DNA-binding sites by different NF-кB subunits in response to activation of distinct kinases illuminates the exquisite regulation of gene expression by the NF-кB pathway.

\section{REGULATION OF IKK $\beta$ ACTIVITY}

IKK $\alpha$ and $-\beta$ dimerize into large signalsomes of approximately $900 \mathrm{kD}$ that contain dimeric complexes of IKK $\alpha$ and IKK $\beta$, tetrameric oligomers of IKK $\gamma(11)$, and HSP90 and CDC37 (12), and potentially other proteins. The kinase domain of IKK $\beta$ contains an activation loop, which contains serine residues 177 and 181, whose phosphorylation is essential to activation of its kinase activity (Figure 2). The relevance of serines 177 and 181 in activating IKK $\beta$ has been established through mutagenesis studies showing that IKK $\beta$ containing serine to alanine mutations at these sites prevents activation of IKK $\beta$, whereas mutation to phosphomimetic glutamic acid residues causes constitutive activation (13). It is worthy of mention that the latter serine to glutamic acid mutation was used to generate a transgenic mouse that inducibly expresses active IKK $\beta$ in airway epithelium, as will be discussed below.

\section{REGULATION OF NF-KB TRANSCRIPTIONAL ACTIVITY}

Nuclear regulation of NF- $\mathrm{B}$ represents a critical component of $\mathrm{NF}-\kappa \mathrm{B}$ activation that dictates the strength and duration of the $\mathrm{NF}-\kappa \mathrm{B}$ transcriptional response, in addition to dictating promoter occupancy (14). NF-кB members become phosphorylated and acetylated, which alters the ability of NF- $\mathrm{KB}$ dimers to bind to DNA, and initiates the recruitment of transcriptional co-activators. These modifications also influence the binding of $\mathrm{NF}-\kappa \mathrm{B}$ to its inhibitor $\mathrm{I} \kappa \mathrm{B} \alpha(4,14)$. RelA can be phosphorylated by multiple kinases that include IKK, which enhances its transactivation potential (see Reference 5 for review). Phosphorylation of RelA by IKK demonstrates that the biological roles of IKK exceed their well-known action in phosphorylation of IкBs. Indeed, recent data suggest that IKK can also regulate other signaling proteins and transcription factors, suggesting that its role far exceeds is function as IкB kinase (15). Of notable significance are observations demonstrating that IKK $\alpha$ causes phosphorylation of histone $\mathrm{H} 3$, silencing mediator of retinoic acid and thyroid hormone receptor (SMRT), and CREB-binding protein (CBP), all important in the control of $\mathrm{NF}-\kappa \mathrm{B}-$ dependent gene transcription (10) (Figure 2). NF- $\mathrm{B}$ relies on the lysine acetylation of histones by histone acetyltransferases (HAT) to initiate DNA uncoiling to enable access and binding of the transcriptional machinery. Both RelA and p50 themselves are acetylated on multiple lysine residues, which regulates different functions of $\mathrm{NF}-\kappa \mathrm{B}$, including transcriptional activation, DNA binding, I $\mathrm{I} \mathrm{B} \alpha$ assembly, and subcellular localization (16). Acetylation of RelA is reversed by histone deacetylases, which cause a loss of transcriptional activation, increases in association with $\mathrm{I} \kappa \mathrm{B} \alpha$, and enhanced nuclear export of NF- $\mathrm{NB}(5)$.

\section{THE ROLE OF ACTIVATION OF NF-KB IN AIRWAY EPITHELIAL CELLS IN ALLERGIC AIRWAY DISEASE}

\section{Lessons from Mouse Models}

Numerous clinical studies have provided solid evidence to support the significance of activation of NF- $\mathrm{B}$ in human asthma $(17,18)$. The murine ovalbumin (OVA) sensitization and challenge model of allergic airway disease has been extensively used by many investigators, including our own laboratory, to unravel the critical cell types, pulmonary com- partments, genes, and molecular signals relevant to the pathophysiology of asthma. In response to sensitization and challenge with OVA (OVA/OVA), mice develop increased airways hyperresponsiveness (AHR) to methacholine, compared with nonsensitized controls (alum/OVA), in association with increases in Th2 cytokines IL-4, IL-5, and IL-13, and eosinophilia (19). Airway remodeling also occurs, exemplified by mucous cell metaplasia, smooth muscle hyperplasia, and enhanced deposition of collagen around the airways (20) (Figure 1). The earliest evidence to support the functional relevance of $\mathrm{NF}-\kappa \mathrm{B}$ in the development of allergic airways disease stemmed from observations in mice that globally lacked members of the NF$\kappa \mathrm{B}$ family. For instance, mice that lacked p50 or c-Rel subunits of NF-кB were protected from the development of allergic airway disease $(21,22)$. While those studies provided insights into the functional importance of $\mathrm{NF}-\mathrm{\kappa B}$ in allergic airways disease, they did not provide information about the cell types, the location, or timing of $\mathrm{NF}-\kappa \mathrm{B}$ activation. Work from our laboratory initially demonstrated that NF-кB activation occurred rapidly in the OVA model of allergic airways disease, and that NF-кB activation occurred predominantly in the epithelial cells of the conducting airways, in association with enhanced mRNA expression of NF- $\mathrm{B}$-regulated chemokine genes, including MIP-2 and eotaxin (19). To address the functional significance of epithelially derived NF- $\kappa$ B activation in the causation of allergic airways disease, a number of mouse models have been developed that took advantage of expression profiles of the rat $\mathrm{CC} 10$ promoter, which is largely restricted to nonciliated bronchial epithelial cells. Our laboratory developed a transgenic mouse expressing a dominant interfering version of $\mathrm{I} \kappa \mathrm{B} \alpha$ in the epithelium of conducting airways, using the rat $\mathrm{CC} 10$ promoter. Compared with wild-type mice, CC10-DN-IкB $\alpha-$ expressing mice demonstrated markedly attenuated inflammatory responses to OVA, in association with less immunoglobin production and mucus metaplasia. Despite these prominent protective effects, CC10-DN-IкB $\alpha$-transgenic mice were not protected from the development of AHR (23). A complimentary approach of conditional deletion of IKK $\beta$ in airway epithelium, achieved through CC10-promoter-controlled expression of CRE recombinase, revealed similar protective effects (24). In the latter study the authors demonstrated marked attenuations in inflammatory responses, including CD4+ T cells, and airway remodeling based on amelioration of mucus metaplasia and dampening of subepithelial fibrosis. To directly evaluate the impact of activation of the canonical NF-кB pathway in epithelial cells in the development of allergic airways disease, in absence of other stimuli, our laboratory more recently generated a transgenic mouse model. As described earlier, IKK $\beta$, the prerequisite enzyme in the canonical NF- $\kappa \mathrm{B}$ activation cascade by most stimuli, requires phosphorylation of serines 177 and 181 in the activation loop to become catalytically active. Thus, a mutant form of IKK $\beta$ where serines 177 and 181 are mutated to phosphomimetic glutamic acids (IKKßS177/181E) has intrinsic catalytic activity (13). This construct was used to create a bi-transgenic mouse that expresses a transgene consisting of the Tet operon driving expression of IKK $\beta S 177 / 181 \mathrm{E}$, and a transgene expressing the doxycycline-inducible reverse tetracycline transactivator under control of the ratCC10 promoter, to induce expression of active IKK $\beta$ after the administration of the tetracycline analog, doxycycline. Induction of the IKK $\beta$ transgene in the airway epithelium caused a predominantly neutrophilic inflammatory response, and was sufficient to induce AHR. Interestingly, AHR occurred in the absence of eosinophils, mucus metaplasia, or production of Th2-associated cytokines (25). However, mice expressing IKK $\beta$ in airway epithelium displayed evidence of smooth muscle thickening, suggesting 
S-nitrosylation

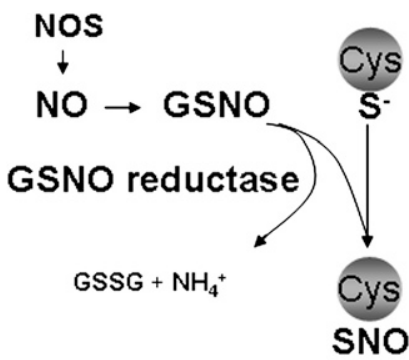

\section{S-glutathionylation}

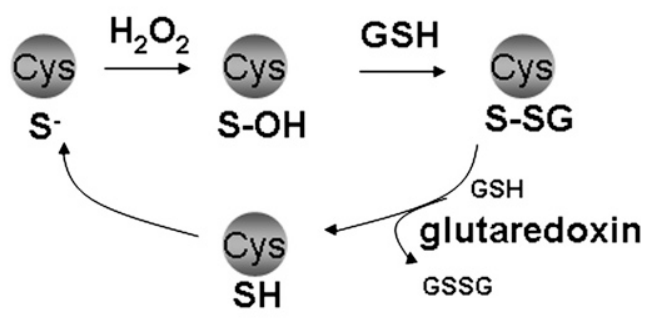

Figure 3. Overview of the biochemical events that control protein S-nitrosylation (SNO) and S-glutathionylation. Nitric oxide synthases (NOS) produce nitric oxide (NO), which can become converted to S-nitrosothiols, including S-nitrosoglutathione (GSNO). S-nitrosothiols can cause protein S-nitrosylation, which exerts important regulatory functions in target proteins. The enzyme, GSNO reductase, metabolizes GSNO and produces ammonia $\left(\mathrm{NH}_{4}{ }^{+}\right)$and oxidized glutathione (GSSG), and indirectly controls protein S-nitrosylation. Hydrogen peroxide $\left(\mathrm{H}_{2} \mathrm{O}_{2}\right)$ can oxidize protein cysteines that are in the thiolate state $\left(\mathrm{S}^{-}\right)$, causing the

formation of unstable sulfenic acid (S-OH) intermediates, which are targets for S-glutathionylation (P-SSG). In physiologic settings, mammalian glutaredoxins serve to reduce the S-glutathionylated proteins, restoring the sulfhydryl (SH) group, thus regulating the extent of PSSG. For detailed information see Reference 29.

a potential mechanistic link between airway epithelial activation and smooth muscle cell biology that is critical to the induction of AHR, the details of which remain to be unraveled. Other findings from the latter study with potential relevance to allergic disease were increases in expression of $\mathrm{CC}$ chemokine ligand 20 (CCL20) and granulocyte macrophage-colony-stimulating factor (GM-CSF) (25), mediators important in the attraction and activation of DCs, loss in inhalational tolerance, and promotion of Th2 immune responses (2) (Figure 1). It will be of interest to determine whether inhalational tolerance is lost in IKK $\beta$-expressing mice, which awaits the outcome of ongoing experiments. Of relevance is a recent study that used pharmacologic approaches to inhibit the IKK signalsome, which resulted in dampening of tissue inflammation, fibrosis, and alveolar remodeling in mice expressing IL-13 in the lung (26). In aggregate, these complimentary transgenic, knock-out, and pharmacologic approaches conclusively define the functional significance of IKK $\beta$ and NF-кB-driven processes within the airway epithelium in the orchestration of a number of events relevant to human asthma.

\section{REDOX CHANGES IN ALLERGIC AIRWAYS DISEASE}

It is well known that asthma and other chronic inflammatory lung disease are associated with enhanced oxidative stress exemplified by elevated levels of nitric oxide (NO) and hydrogen peroxide $\left(\mathrm{H}_{2} \mathrm{O}_{2}\right)$ in exhaled breath condensates in patients with asthma $(27,28)$. These oxidants can arise after the activation of NADPH oxidases and nitric oxide synthases present in inflammatory, but also in structural lung cells (29). Increased levels of the stable oxidation endproducts, such as 3-nitrotyrosine, in general correlate directly with the intensity of inflammation and asthma severity (30), and the fraction of exhaled NO is currently used as a marker of disease severity. Environmental agents that are known to cause asthma exacerbations, like nitrogen dioxide, ozone, cigarette smoke, and pollen, also increase the oxidative burden in the lung. Inactivation of antioxidant enzymes and loss of glutathione levels that have been observed in patients with asthma further contribute to the increased oxidative stress in the lung tissue (31). These collective observations, coupled to studies

\section{Canonical pathway}

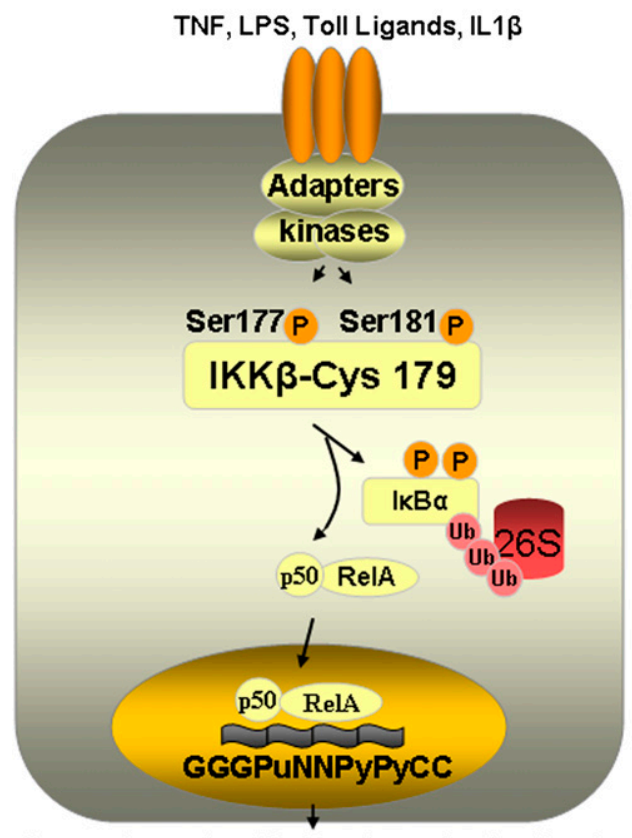

Genes important in innate and adaptive immunity and inhibition of apoptosis

\section{Canonical pathway}

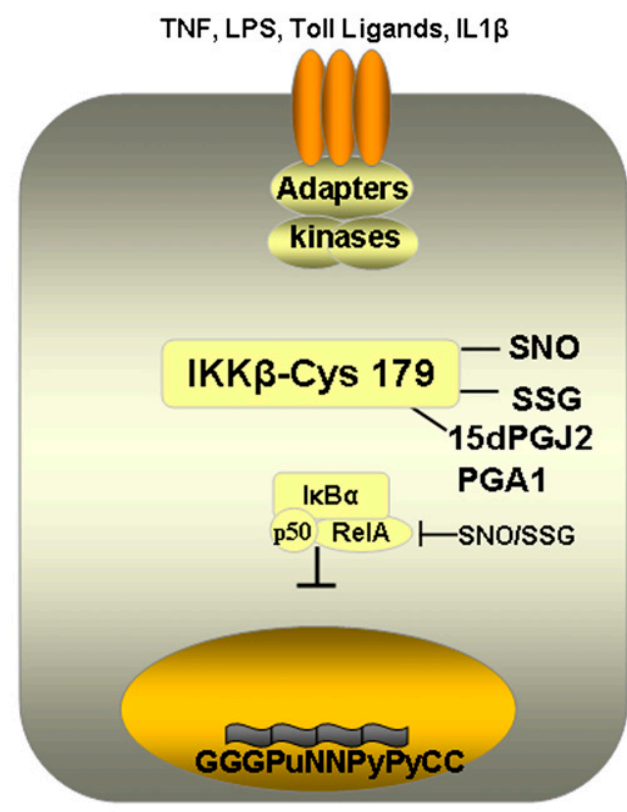

Figure 4. Overview of activation of the canonical (classical) NF-кB pathway, and visualization of the inhibitory effect of cysteine oxidation of IKK $\beta$ at cysteine 179 on activation of the NF-kB pathway. We have also highlighted that the same cysteine is targeted by the antiinfammatory prostaglandins, PGA1 and 15dPG)2. $15 \mathrm{dPG} 2=15$-deoxy- $\Delta^{12-14}$. prostaglandin $\mathrm{J}_{2} ; \mathrm{PGA} 1=$ prostaglandin $\mathrm{A} 1$; $\mathrm{SNO}=\mathrm{S}$ nitrosylation; SSG $=$ S-glutathionylation. Inhibition of RelA and p50 after S-nitrosylation and S-glutathionylation is also highlighted. 
demonstrating that compounds with antioxidant properties ameliorate the severity of disease in mouse models (32), have led to the widely held notion that enhanced oxidative stress contributes to the pathogenesis of asthma. While certain redox changes that occur in the inflamed lung may well contribute to the disease process, the exact mode whereby oxidants contribute to lung disease has remained elusive. One plausible scenario is the causation of cell injury, or necrotic cell death, which cause barrier disruption and subsequent proinflammatory responses due the stimulation of receptors that sense and respond to danger signals.

However, a completely different view is currently emerging that is centered around the role of oxidants as signaling molecules critical to tissue homeostasis and innate host defense. This concept of "redox biology" is based on the recently gained appreciation that nitric oxide and hydrogen peroxide cause specific oxidations in target cysteines within proteins, which exert regulatory functions, dependent on the protein that is being targeted. NO, through the formation of S-nitrosothiol intermediates (SNO), can lead to a post-translational modification of protein cysteine residues known as S-nitrosylation (Figure 3, left). $\mathrm{H}_{2} \mathrm{O}_{2}$ can react with select protein cysteines to give rise to sulfenic acid intermediates (SOH), which subsequently can become glutathionylated (Figure 3, right). Note that S-nitrosothiols can also cause S-glutathionylation. Sglutathionylation thus represents the covalent modification of protein cysteines with the tri-peptide, glutathione (also known as protein mixed disulfides or protein [P]-SSG). It is important to recognize that not all cysteines are oxidizable; only low $\mathrm{p} K_{\mathrm{a}}$ cysteines in the thiolate form $\left(\mathrm{S}^{-}\right)$, referred to as reactive cysteines, can be oxidized, conferring substantial specificity to these oxidation events. The enzyme GSNO reductase decomposes the S-nitrosothiol, S-nitrosoglutathione (GSNO), and indirectly controls the tone of protein S-nitrosylation. Furthermore, mammalian glutaredoxins under physiologic conditions act to specifically reverse S-glutathionylated proteins (Figure 3). Similarly, the thioredoxin (Trx) system of enzymes catalyzes the reversible reduction of disulfides, thereby resulting in a dithiolcontaining target protein, and a disulfide in Trx, which is subsequently reduced by thioredoxin reductase. The existence of these and other enzymes to directly or indirectly regulate the oxidation state of protein cysteines gives additional credence to the relevance of protein oxidation events in cell biology and disease (reviewed in Reference 29). Indeed, many proteins with signaling functions that range from membrane proteins and proteases to transcription factors, are regulated via $\mathrm{S}$ nitrosylation, S-glutathionylation, or disulfides. While the role of S-glutathionylation in asthma remains to be unraveled, a wealth of compelling observations have illuminated a loss of S-nitrosothiols and S-nitrosylation, in allergic airways disease (33). Loss of S-nitrosothiols is potentially due to increases in GSNO reductase, the aforementioned enzyme that controls decomposition of S-nitrosothiols, which has been identified as a key regulator of AHR $(29,34)$. These significant recent observations raise the intriguing possibility that loss of protective or homeostatic oxidative events is critical in the pathogenesis of allergic airways disease.

\section{REDOX REGULATION OF NF-кB}

\section{Activation or Inhibition by Oxidants?}

It has been known for well over a decade that NF- $\mathrm{BB}$ is a redoxsensitive transcription factor, a topic that has been reviewed extensively (5). NF- $\mathrm{\kappa B}$ activation by diverse proinflammatory stimuli, including IL- $1 \beta$, has been demonstrated to require reactive oxygen species (ROS) in part after activation of NADPH oxidases $(35,36)$, and mitochondrial ROS in certain contexts also can lead to activation of NF-кB $(37,38)$. However, is it not clear whether the oxidative events triggered by those stimuli are specific to components of the NF- $\mathrm{B}$ pathway, and information about the cysteine residues that are being targeted remain unraveled. In fact, the physiologic role for oxidants in the activation of $\mathrm{NF}-\kappa \mathrm{B}$ has extensively questioned by studies demonstrating that redox activation is cell type specific $(39,40)$, and that various antioxidants were nonspecific in their actions (41). Evidence also exists that NADPH oxidase-induced ROS do not mediate NF- $\kappa \mathrm{B}$ signaling, but lower the magnitude of its

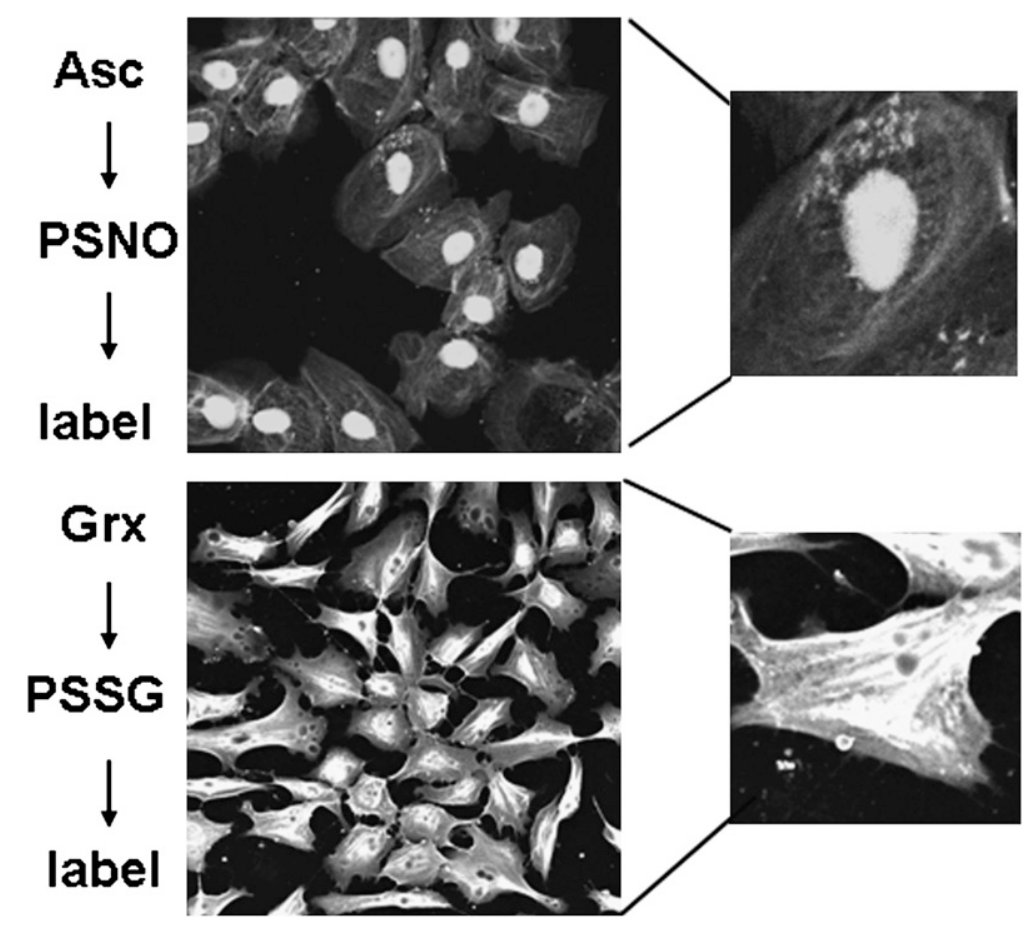

Figure 5. Detection of protein S-nitrosylation (PSNO) and protein S-glutathionylation (PSSG) in intact C10 lung epithelial cells. Control cells were fixed and subjected to thiol blocking, ascorbate dependent decomposition of S-nitrosylated proteins, and subsequent biotin labeling of newly generated reduced sulfhydryls using a biotin-conjugated probe, incubation with streptavidin-conjugated fluorophore, and detection via confocal laser scanning flow cytometry. S-glutathionylated proteins were visualized after glutaredoxin-catalyzed reduction of S-glutathionylated proteins. Details of these procedures were reviewed elsewhere (29). 
activation (41). Indeed, a number of reports, including work from our laboratory demonstrate that oxidants can specifically inhibit the NF-кB pathway in lung epithelial cells via S-nitrosylation or S-glutathionylation of cysteine 179 of IKK $\beta$ $(42,43)$, the same cysteine also targeted by antiinflammatory cyclopentenone prostaglandins (44) (Figure 4). It is likely that additional cysteine oxidative events that include modification of p50 (45) and RelA (46) also contribute to oxidative inhibition of $\mathrm{NF}-\kappa \mathrm{B}$. These observations suggest that certain regulatory oxidative events could play important antiinflammatory roles in lung and other tissues by limiting the activation of NF- $\mathrm{BB}$.

\section{CONCLUDING REMARKS AND RECOMMENDATIONS FOR FUTURE STUDIES}

Guilt by association has linked the activation of $\mathrm{NF}-\kappa \mathrm{B}$ and increases in oxidative stress in asthma. However, despite many years of investigation into the mechanism whereby oxidants affect the pathophysiology of asthma, their exact roles in the disease process has remained enigmatic. This in part stems from the fact that multiple interconnected redox changes occur simultaneously in inflamed lung disease. Furthermore, an inability to probe oxidative events that have biological relevance, notably S-nitrosylation and S-glutathionylation, due to lack of specific tools to detect these oxidative events in biological settings impeded scientific progress. Exciting new momentum was initiated recently based on approaches to trap and label proteins that are targeted by S-nitrosylation and S-glutathionylation, which enables investigators to determine for the first time which proteins are regulated via cysteine oxidations and furthermore allows the detection of S-nitrosylation and S-glutathionylation in intact cells and tissues (Figure 5) (29). These approaches may have significance based on a wealth of observations demonstrating that NF- $\mathrm{B}$ can indeed be inhibited via cysteine oxidative events. Documentation that cysteine oxidative events, targeted to the NF-кB pathway, occur in vivo, and are affected in allergic lung disease may provide new therapeutic opportunities to regulate certain facets of its activation.

Conflict of Interest Statement: Y.M.W.J.-H. has U.S. patents pending: Treatment involving glutaredoxins, Detection of S-glutathionylated proteins, and Detection of S-nitrosylated proteins. M.E.P. is the recipient of a research grant and lecture fees from Sepracor, Inc. S.W.A. has a U.S. patent pending: Treatment involving glutaredoxins. C.P. does not have a financial relationship with a commercial entity that has an interest in the subject of this manuscript. J.L.A. does not have a financial relationship with a commercial entity that has an interest in the subject of this manuscript. N.L.R. is co-inventor on the following patents: Detection of glutathionylated proteins (U.S. Pat. Apl. Ser. No.: 11/698,300), Treatments Involving Glutaredoxins and Similar Agents (U.S. Pat. Apl. Ser. No.: 60/ 934,129 ) and Detection of nitrosylated proteins (US publication number 200502874, International publication number WO2005/101019). K.C. has a U.S. patent pending: Detection of S-nitrosylated proteins. V.A. does not have a financial relationship with a commercial entity that has an interest in the subject of this manuscript. J.v.d.V. does not have a financial relationship with a commercial entity that has an interest in the subject of this manuscript. C.G.I. does not have a financial relationship with a commercial entity that has an interest in the subject of this manuscript. A.v.d.V. has a patent pending: Detection of S-nitrosylated proteins.

Acknowledgment: The authors apologize for not being able to mention or reference the cardinal work of many of our colleagues due to space constraints.

\section{References}

1. Bousquet J, Jeffery PK, Busse WW, Johnson M, Vignola AM. Asthma: from bronchoconstriction to airways inflammation and remodeling. Am J Respir Crit Care Med 2000;161:1720-1745.

2. Hammad H, Lambrecht BN. Dendritic cells and epithelial cells: linking innate and adaptive immunity in asthma. Nat Rev 2008;8:193-204.

3. Church LD, Cook GP, McDermott MF. Primer: inflammasomes and interleukin 1beta in inflammatory disorders. Nat Clin Pract Rheumatol 2008;4:34-42.

4. Hayden MS, Ghosh S. Signaling to NF-kappaB. Genes Dev 2004;18: 2195-2224.
5. Pantano C, Reynaert NL, van der Vliet A, Janssen-Heininger YM. Redox-sensitive kinases of the nuclear factor-kappaB signaling pathway. Antioxid Redox Signal 2006;8:1791-1806.

6. Rudolph D, Yeh WC, Wakeham A, Rudolph B, Nallainathan D, Potter J, Elia AJ, Mak TW. Severe liver degeneration and lack of NF-kappaB activation in NEMO/IKKgamma-deficient mice. Genes Dev 2000;14: 854-862.

7. DiDonato JA, Hayakawa M, Rothwarf DM, Zandi E, Karin M. A cytokine-responsive IkappaB kinase that activates the transcription factor NF-kappaB. Nature 1997;388:548-554.

8. Senftleben U, Cao Y, Xiao G, Greten FR, Krahn G, Bonizzi G, Chen Y, $\mathrm{Hu}$ Y, Fong A, Sun SC, et al. Activation by IKKalpha of a second, evolutionary conserved, NF-kappa B signaling pathway. Science 2001; 293:1495-1499.

9. Bonizzi G, Bebien M, Otero DC, Johnson-Vroom KE, Cao Y, Vu D, Jegga AG, Aronow BJ, Ghosh G, Rickert RC, et al. Activation of IKKalpha target genes depends on recognition of specific kappaB binding sites by relb:P52 dimers. EMBO J 2004;23:4202-4210.

10. Ghosh S, Hayden MS. New regulators of NF-kappaB in inflammation. Nat Rev 2008;8:837-848.

11. Karin M. How NF-kappaB is activated: The role of the IkappaB kinase (IKK) complex. Oncogene 1999;18:6867-6874.

12. Chen G, Cao P, Goeddel DV. TNF-induced recruitment and activation of the IKK complex require CDC37 and HSP90. Mol Cell 2002;9:401-410.

13. Delhase M, Hayakawa M, Chen Y, Karin M. Positive and negative regulation of IkappaB kinase activity through IKKbeta subunit phosphorylation. Science 1999;284:309-313.

14. Chen LF, Greene WC. Shaping the nuclear action of NF-kappaB. Nat Rev Mol Cell Biol 2004;5:392-401.

15. Perkins ND. Integrating cell-signalling pathways with NF-kappaB and IKK function. Nat Rev Mol Cell Biol 2007;8:49-62.

16. Chen L, Fischle W, Verdin E, Greene WC. Duration of nuclear NF-kappaB action regulated by reversible acetylation. Science 2001;293:1653-1657.

17. Hart LA, Krishnan VL, Adcock IM, Barnes PJ, Chung KF. Activation and localization of transcription factor, nuclear factor-kappaB, in asthma. Am J Respir Crit Care Med 1998;158:1585-1592.

18. Hamilton LM, Davies DE, Wilson SJ, Kimber I, Dearman RJ, Holgate ST. The bronchial epithelium in asthma-much more than a passive barrier. Monaldi Arch Chest Dis 2001;56:48-54.

19. Poynter ME, Irvin CG, Janssen-Heininger YM. Rapid activation of nuclear factor-kappaB in airway epithelium in a murine model of allergic airway inflammation. Am J Pathol 2002;160:1325-1334.

20. Ramos-Barbon D, Ludwig MS, Martin JG. Airway remodeling: Lessons from animal models. Clin Rev Allergy Immunol 2004;27:3-21.

21. Yang L, Cohn L, Zhang DH, Homer R, Ray A, Ray P. Essential role of nuclear factor kappaB in the induction of eosinophilia in allergic airway inflammation. J Exp Med 1998;188:1739-1750.

22. Donovan CE, Mark DA, He HZ, Liou HC, Kobzik L, Wang Y, De Sanctis GT, Perkins DL, Finn PW. NF-kappa B/rel transcription factors: C-rel promotes airway hyperresponsiveness and allergic pulmonary inflammation. J Immunol 1999;163:6827-6833.

23. Poynter ME, Cloots R, van Woerkom T, Butnor KJ, Vacek P, Taatjes DJ, Irvin CG, Janssen-Heininger YM. NF-kappa B activation in airways modulates allergic inflammation but not hyperresponsiveness. J Immunol 2004;173:7003-7009.

24. Broide DH, Lawrence T, Doherty T, Cho JY, Miller M, McElwain K, McElwain S, Karin M. Allergen-induced peribronchial fibrosis and mucus production mediated by IkappaB kinase beta-dependent genes in airway epithelium. Proc Natl Acad Sci USA 2005;102:17723-17728.

25. Pantano C, Ather JL, Alcorn JF, Poynter ME, Brown AL, Guala AS, Beuschel SL, Allen GB, Whittaker LA, Bevelander M, et al. Nuclear factor-kappaB activation in airway epithelium induces inflammation and hyperresponsiveness. Am J Respir Crit Care Med 2008;177:959-969.

26. Chapoval SP, Al-Garawi A, Lora JM, Strickland I, Ma B, Lee PJ, Homer RJ, Ghosh S, Coyle AJ, Elias JA. Inhibition of NF-kappaB activation reduces the tissue effects of transgenic il-13. J Immunol 2007;179:7030-7041.

27. Antczak A, Nowak D, Shariati B, Krol M, Piasecka G, Kurmanowska Z. Increased hydrogen peroxide and thiobarbituric acid-reactive products in expired breath condensate of asthmatic patients. Eur Respir J 1997;10:1235-1241.

28. Emelyanov A, Fedoseev G, Abulimity A, Rudinski K, Fedoulov A, Karabanov A, Barnes PJ. Elevated concentrations of exhaled hydrogen peroxide in asthmatic patients. Chest 2001;120:1136-1139.

29. Janssen-Heininger YM, Mossman BT, Heintz NH, Forman HJ, Kalyanaraman B, Finkel T, Stamler JS, Rhee SG, van der Vliet A. 
Redox-based regulation of signal transduction: principles, pitfalls, and promises. Free Radic Biol Med 2008;45:1-17.

30. Saleh D, Ernst P, Lim S, Barnes PJ, Giaid A. Increased formation of the potent oxidant peroxynitrite in the airways of asthmatic patients is associated with induction of nitric oxide synthase: effect of inhaled glucocorticoid. FASEB J 1998;12:929-937.

31. Ghosh S, Janocha AJ, Aronica MA, Swaidani S, Comhair SA, Xu W, Zheng L, Kaveti S, Kinter M, Hazen SL, et al. Nitrotyrosine proteome survey in asthma identifies oxidative mechanism of catalase inactivation. J Immunol 2006;176:5587-5597.

32. Chang LY, Crapo JD. Inhibition of airway inflammation and hyperreactivity by an antioxidant mimetic. Free Radic Biol Med 2002;33:379-386.

33. Gaston B, Singel D, Doctor A, Stamler JS. S-nitrosothiol signaling in respiratory biology. Am J Respir Crit Care Med 2006;173:1186-1193.

34. Que LG, Liu L, Yan Y, Whitehead GS, Gavett SH, Schwartz DA, Stamler JS. Protection from experimental asthma by an endogenous bronchodilator. Science 2005;308:1618-1621.

35. Bonizzi G, Piette J, Schoonbroodt S, Greimers R, Havard L, Merville MP, Bours V. Reactive oxygen intermediate-dependent NF-kappaB activation by interleukin-1beta requires 5-lipoxygenase or NADPH oxidase activity. Mol Cell Biol 1999;19:1950-1960.

36. Li Q, Engelhardt JF. Interleukin-1beta induction of NFkappaB is partially regulated by $\mathrm{H} 2 \mathrm{O} 2$-mediated activation of NFkappaBinducing kinase. J Biol Chem 2006;281:1495-1505.

37. Chandel NS, Schumacker PT, Arch RH. Reactive oxygen species are downstream products of traf-mediated signal transduction. $J$ Biol Chem 2001;276:42728-42736.

38. Hughes G, Murphy MP, Ledgerwood EC. Mitochondrial reactive oxygen species regulate the temporal activation of nuclear factor kappaB to modulate tumour necrosis factor-induced apoptosis: evidence from mitochondria-targeted antioxidants. Biochem J 2005;389:83-89.
39. Anderson MT, Staal FJ, Gitler C, Herzenberg LA. Separation of oxidant-initiated and redox-regulated steps in the NF-kappa B signal transduction pathway. Proc Natl Acad Sci USA 1994;91:11527-11531.

40. Brennan P, O'Neill LA. Effects of oxidants and antioxidants on nuclear factor kappa B activation in three different cell lines: evidence against a universal hypothesis involving oxygen radicals. Biochim Biophys Acta 1995;1260:167-175.

41. Hayakawa M, Miyashita H, Sakamoto I, Kitagawa M, Tanaka H, Yasuda $\mathrm{H}$, Karin M, Kikugawa K. Evidence that reactive oxygen species do not mediate NF-kappaB activation. EMBO J 2003;22:3356-3366.

42. Reynaert NL, Ckless K, Korn SH, Vos N, Guala AS, Wouters EF, van der Vliet A, Janssen-Heininger YM. Nitric oxide represses inhibitory kappaB kinase through S-nitrosylation. Proc Natl Acad Sci USA 2004; 101:8945-8950.

43. Reynaert NL, van der Vliet A, Guala AS, McGovern T, Hristova M, Pantano C, Heintz NH, Heim J, Ho YS, Matthews DE, et al. Dynamic redox control of NF-kappaB through glutaredoxin-regulated Sglutathionylation of inhibitory kappab kinase beta. Proc Natl Acad Sci USA 2006;103:13086-13091.

44. Rossi A, Kapahi P, Natoli G, Takahashi T, Chen Y, Karin M, Santoro MG. Anti-inflammatory cyclopentenone prostaglandins are direct inhibitors of IkappaB kinase. Nature 2000;403:103-108.

45. Matthews JR, Wakasugi N, Virelizier JL, Yodoi J, Hay RT. Thioredoxin regulates the DNA binding activity of NF-kappa B by reduction of a disulphide bond involving cysteine 62. Nucleic Acids Res 1992;20: 3821-3830.

46. Kelleher ZT, Matsumoto A, Stamler JS, Marshall HE. NOS2 regulation of NF-kappaB by S-nitrosylation of p65. J Biol Chem 2007;282:3066730672 .

47. Hayden MS, Ghosh S. Shared principles in NF-kappaB signaling. Cell 2008;132:344-362. 